University of Novi Sad, Faculty of Medicine ${ }^{1}$

Department of Pharmacology, Toxicology and Clinical Pharmacology ${ }^{2}$
Original study

Originalni naučni rad

UDK 615.25.03-055.26

DOI: $10.2298 /$ MPNS1602011H

\title{
DRUG UTILIZATION IN TREATMENT OF THYROID DISORDERS DURING PREGNANCY IN SERBIA
}

\author{
UPOTREBA LEKOVA U LEČENJU BOLESTI ŠTITASTE ŽLEZDE TOKOM TRUDNOĆE U SRBIJI
}

\author{
Olga HORVAT ${ }^{1,2}$, Zdenko TOMIĆ ${ }^{1,2}$, Vesna MIJATOVIĆ ${ }^{1,2}$ and Ana SABO ${ }^{1,2}$
}

\begin{abstract}
Summary
Introduction. Depleted uranium radiation and pollution with polychlorinated biphenyls resulting from bombings the territories of Serbia as well as the additional long-term stress may have affected the function of thyroid gland. The objective of this study was to determine the trend of drug utilization in the treatment of thyroid dysfunction during pregnancy in Novi Sad. Material and Methods. Women who had given birth at the Department of Gynecology in 1989, 1999, 2007 and 2011 were interviewed during a one-month period about thyroid diseases in the pregnancy as well as the drugs they had taken. Results. Not a single pregnant woman was reported to have a thyroid disorder in 1989 and 1999, while in 2007 four women were reported to have a thyroid dysfunction. In 2011, fourteen out of 18 women with thyroid dysfunction were using levothyroxine and in most cases hypothyroidism was diagnosed as autoimmune Hashimoto thyroiditis. Conclusion. The study results suggest the necessity of performing more detailed analyses of the correlation between the frequency of the thyroid gland dysfunction and the effects of environmental pollution in Serbia.

Key words: Thyroid Diseases; Pregnancy; Hashimoto Disease; Hypothyroidism; Propylthiouracil; Thyroxine; Risk Factors; Drug Therapy; Epidemiology; Serbia
\end{abstract}

\section{Introduction}

A wide variety of environmental agents affect the thyroid gland causing different thyroid function disorders and one of the well-known environmental catastrophes was the Chernobyl accident, when a significant correlation between the exposure to radioactive iodine $\mathrm{J}^{131}$ and the incidence of hypothyroidism was determined $[1,2]$. This catastrophe led to the increased frequency of juvenile hypothyroidism in Belarus, the Russian Federation and Ukraine ten years later [3].

\footnotetext{
Acknowledgements

This work was supported by the Ministry of Science and Technological Development, Republic of Serbia (project No. 41012) and by the Provincial Secretariat for Science and Technological Development, Autonomous Province of Vojvodina (grant No. 114-451-3551/2013-02)
}

\section{Sažetak}

Uvod. Od zagađujućih supstancija, kao rezultat konfliktnih situacija na području Srbije, značajno mesto zauzimaju osiromašeni uranijum i polihlorovani bifenili koji, uz propratni dugotrajni stres, značajno utiču na funkciju štitaste žlezde. Cilj rada bio je da se odredi trend upotrebe lekova u terapiji bolesti štitaste žlezde tokom trudnoće na teritoriji grada Novog Sada. Materijal i metode. Tokom jednomesečnog perioda anketirane su sve porodilje hospitalizovane na Klinici za ginekologiju i akušerstvo 1989, 1999, 2007. i 2011. godine, o bolestima štitaste žlezde, kao i o tome koji lek uzimaju u terapiji poremećaja funkcije štitaste žlezde. Rezultati. Tokom 1989. i 1999. godine nijedna trudnica nije evidentirana sa poremećajem funkcije štitaste žlezde, 2007. godine evidentirane su 4 trudnice, a 2011. godine bilo je 18 trudnica sa poremećajem funkcije štitaste žlezde od čega čak 14 sa dijagnozom hipotiroze i to u najvećem broju slučaja kao autoimuni Hašimotov tiroiditis. Zaključak. Rezulati našeg rada ukazuju na neophodnost sprovođenja detaljnije analize povezanosti učestalosti ovih poremećaja funkcije štitaste žlezde i uticaja zagađivača životne sredine.

Ključne reči: Oboljenja štitne žlezde; Trudnoća; Hašimotova bolest; Hipotireoza; Propiltiouracil; Tiroksin; Faktori rizika; Terapija; Epidemiologija; Srbija

During the end stage of conflict period in the Balkans (in 1999), a partial or total destruction of industrial plants, military targets, infrastructure, as well as uncontrolled fires and explosions resulted in large amounts of hazardous organic matter that were generated and emitted into the environment, and the city of Novi Sad was recognized as an environmental hot spot by the United Nations Environment Programme and the United Nations Centre for Human Settlements [4]. About 73,000 tons of crude oil and oil products, including the transformer oil containing polychlorinated biphenyls (PCBs) were burned or leaked (UNEP/UNCHS Report, 1999) during the bombing of the Novi Sad oil refinery in 1999 [5]. The effect of PBC exposure on serum thyroid hormone levels is well documented in animals and humans [5-8]. Some of the studies have shown that the increased prevalence of some 


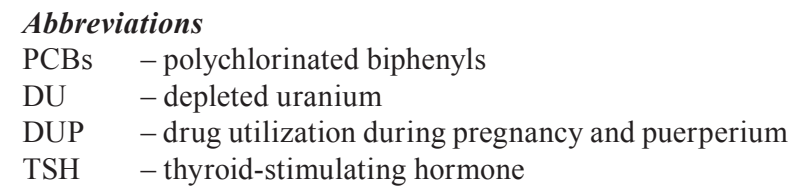

thyroid antibodies may be related to the known immunomodulatory effects of PCBs $[9,10]$. Depleted uranium (DU), an emerging environmental pollutant, was used as armor-penetrating ammunition in the Balkans conflict and was claimed to contribute to health problems $[11,12]$. Studies investigating DU health effects at the cellular level or on animals exposed to DU suggest a possible influence on birth defects, immune system impairments, cancer risk etc. $[13,14]$.

Maintenance of normal thyroid function is essential for psychological and physiological well-being. Pregnant women with undiagnosed or inadequately treated hypothyroidism have an increased risk of miscarriage, preterm delivery, and severe developmental problems in their children $[15,16]$. Therefore, the aim of our study was to determine the trend of thyroid function disorders through monitoring the utilization of drugs for the treatment of thyroid gland disorders in pregnant women, as the most vulnerable group of population in the city of Novi Sad, Serbia, before and after the conflict period in the Balkans.

\section{Material and Methods}

A survey was performed in Novi Sad, Serbia, a city with about 300,000 inhabitants, with only one
Department of Gynecology and Obstetrics. The Regional Ethics Committee approved the survey. The study sample consisting only of women who had signed the informed consent form, thus showing that they were willing to participate in the survey.

This retrospective-prospective study included the pregnant women who had given birth at the Ward of Perinatology, Department of Gynecology and Obstetrics during the one month period in 1989, 1999, 2007 and 2011. The study was the extension of multinational DUP study (Drug utilization during pregnancy and puerperium) [17, 18].

Data about drugs used for thyroid function disorders during pregnancy were taken from the health files of parturients.

\section{Results}

Table 1 shows the trend in the drug utilization in treatment of thyroid dysfunction in pregnant women from 1988 to 2011 in Novi Sad.

In years 1988 and 1999 no drugs were used for treatment of thyroid dysfunction in pregnant women included in the surveys (296 and 100 pregnant women, respectively).

In 2007, four out of 423 pregnant women included in the study were reported to have thyroid dysfunction. Three $(0.70 \%)$ out of four had hypothyroidism and all of them were administered levothyroxine replacement therapy, while one pregnant woman had hyperthyroidism.

In 2011, 18 out of 413 pregnant women included in the study were reported to have thyroid dysfuncti-

Table 1. The prevalence of the thyroid dysfunction in pregnant women suffering from hypothyroidism and hyperthyroidism included in the survey at the Ward of Perinatology, Department of Gynecology and Obstetrics, Clinical Center Novi Sad in 1988, 1999, 2007 and 2011.

Tabela 1. Prevalencija poremećaja funkcije štitaste žlezde kod trudnica obolelih od hipotiroze i hipertiroze uključenih u ispitivanje na Zavodu za perinatologiju, Klinike za Ginekologiju i akušerstvo Kliničkog centra u Novom Sadu 1988., 1999., 2007. i 2011. godine.

\begin{tabular}{lcccc}
\hline & $1989 *$ & $1999^{* *}$ & $2007 * *$ & 2011 \\
\hline $\begin{array}{l}\text { Total No of included pregnant women } \\
\text { Ukupan broj porodilja uključenih u ispitivanje }\end{array}$ & 296 & 100 & 423 & 413 \\
$\begin{array}{l}\text { Total No and percentage of pregnant women with thyroid gland disorders } \\
\text { Ukupan broj i procenat porodilja sa poremećajem funkcije štitne žlezde }\end{array}$ & 0 & 0 & $4(0.93 \%)$ & $18(4.23 \%)$ \\
$\begin{array}{l}\text { Total No and percentage of pregnant women with hypothyroidism } \\
\text { Ukupan broj i procenat porodilja hipotireozom }\end{array}$ & 0 & 0 & $3(0.70 \%)$ & $14(3.39 \%)$ \\
$\begin{array}{l}\text { Total No and percentage of pregnant women with hyperthyroidism } \\
\text { Ukupan broj i procenat porodilja hipertireozom }\end{array}$ & 0 & 0 & $1(0.23 \%)$ & $4(0.97 \%)$ \\
\hline
\end{tabular}

* data about incidence of the thyroid disorders were taken from the Study on Drug Use in Pregnancy (DUP) initiated by the Mario Negri Institute, Milano, Italy, conducted in 1989, when Novi Sad was one of the centres of the study. The follow-up study was performed 10 years later in 1999 (Sabo et al., 2001)

** data about incidence of the thyroid disorders were taken from the unpublished data of the Department of Pharmacology, Toxicology and Clinical Pharmacology, Faculty of Medicine, University of Novi Sad

* podaci o učestalosti oboljenja štitaste žlezde kod trudnica preuzeti su iz istraživanja o upotrebi lekova u trudnoći-DUP (Drug Use in Pregnancy) koji je pokrenuo Institut Mario Negri, Milano, Italija, sprovedenog 1989. godine kada je Novi Sad bio jedan od centara ovog istraživanja. Nastavak ovog istraživanja sproveden je 10 godina kasnije 1999. godine [17]

** podaci o učestalosti oboljenja štitaste žlezde kod trudnica preuzeti su iz neobjavljenih podataka Katedre za farmakologiju, toksikologiju i kliničku farmakologiju 
on. The replacement therapy of levothyroxine for the treatment of hypothyroidism was taken by $14(3.39 \%)$ women during pregnancy out of 413 women included in the study, with the average duration of the treatment with levothyroxine sodium of $3.3 \pm 2.59$ years. Autoimmune Hashimoto's thyroiditis was diagnosed in $64.28 \%$ of them. The average duration of treatment with propylthiouracil was $1.6 \pm 0.94$ years in four pregnant women with hyperthyroidism.

\section{Discussion}

Thyroid disorders are the second most common endocrine disorders found in pregnancy. However, data on epidemiology of thyroid diseases are scarce [19-21]. The epidemiology data vary widely, with overt hypothyroidism occurring in $0.3-0.5 \%$ [22] to $12.8 \%$ of pregnancies $[22,23]$. Subclinical disorders appear to occur from $2-3 \%$ to $25 \%$ [21-24]. Therefore, the more accurate way of assessing the epidemiology of thyroid dysfunction is to follow the prevalence in time rather than to compare epidemiology between the countries.

In Novi Sad study the percentage of pregnant women taking drugs for hormonal disorders increased more than 4-fold between the last two study periods. Having in mind the significance of hypothyroidism on fetal development, such a high increase in the number of young pregnant women with hypothyroidism is alarming.

According to the published data, numerous reasons can trigger the autoimmune process affecting the thyroid gland, chemical factors and long-term stress being well recognized. The ammunition containing depleted uranium was used in military operations by NATO in all parts of Serbia during the Kosovo conflict in 1999. Public concern related to health consequences has been raised by the general belief that Novi Sad and the region of Vojvodina were contaminated by depleted uranium during the bombing. Some studies in animals have shown the immune modulation ability of DU. It can cause inappropriate apoptosis of murine (mouse) peritoneal macrophages, which can lead to both autoimmune problems and immusuppression. The similarities between murine and human immune system genetics suggest that these findings may also apply to humans [25]. The analysis of 50 soil samples taken from the region of Vojvodina after the conflict showed slight increases in the activity of $137 \mathrm{Cs}$, which has a negative impact on the environment, from 6.6 in 1989 to $8.2 \mathrm{~Bq} / \mathrm{kg}$ in 2001 in the region of Novi Sad and from 23 to $31 \mathrm{~Bq} / \mathrm{kg}$ in the region of Vršac [26]. Most of 137Cs originates from Chernobyl disaster [27]. However, while the values in Novi Sad and Vršac slightly increased after 1999, in Subotica region which had not been bombed, with time the activity of $137 \mathrm{Cs}$ had the tendency to decline from 9Bq/kg in 1999 to $4,6 \mathrm{~Bq} / \mathrm{kg}$ in 2001 year. Contamination with inhaled DU was proved by the excretion of DU isotopes in the urine of exposed military personnel seven years after the Balkans conflict according to Durakovic (2001) [11].

Skrbić and Miljević investigated the soil pollution at the oil refinery in Novi Sad following the destruction of crude oil and its products in storage tanks during the Kosovo conflict by taking the soil samples from several fields of the oil refinery [28]. At some locations the presence of $\mathrm{PCBs}$, another important environment pollutant, indicated the burning of additives stored at the refinery site. The contamination with PCBs presents a great environmental risk, especially for drinking water (the oil refinery of Novi Sad is located just $0.5 \mathrm{~km}$ upstream of bank filtration wells used for the city's water supply) due to the potential migration of identified pollutants by groundwater to infiltration galleries [29]. In adults, adolescents and children from highly PCB-exposed areas the concentration of PCB in blood samples correlated negatively to the levels of circulating peripheral thyroid hormones [30]. The levels of PCBs in the environment are associated with reduced thyroid hormone levels in the pregnant women [31, 32]. Prenatal or postnatal exposure of humans or animals to $\mathrm{PBC}$ can result in hormonal changes and neurodevelopment deficits $[33,34]$. The longterm exposure to heavy environment pollution among the employees of PBCs factory in Slovakia resulted in a significant increase of autoantibodies against thyroid peroxidase (TPO Ab) as well as a higher prevalence of autoantibodies against thyroglobulin (Tg Ab) and autoantibodies against TSH (TSHR Ab) especially in female employees compared to the control group [35].

Numerous other reasons can affect the prevalence of dysfunction of thyroid gland, long-lasting stress being one of them [36]. Studies including soldiers after the war and victims of abuse have shown abnormal values of TSH, triiodthyromine (T3) and thyroxine (T4), with mostly decreased values of thyroid hormones. The effects of chronic stress during the civil war in Serbia have not been investigated yet. Its long lasting consequences in combination with environment pollutants includes not only disturbances of homeostasis, but also a potentially deadly disease such as an increased number of malformations in newborns and different forms of cancer in adults $[2,37,38]$.

\section{Limitation of the Study}

A shortcoming of this study is the absence of data on the prevalence of thyroid disorders in pregnant women, namely the hypothyroidism, which results from insufficient epidemiology data in Serbia. The translation of results of comparative research of thyroid disorders prevalence is hard to conduct due to differences in definition and samples of population as well as the fact that the use of unique series of diagnostic criteria for the prevalence of these disorders are necessary. The data about the possible causes of environment pollution and stress on hypothyroidism in pregnancy 
are scarce, and conclusions about their influence on pregnancy are insufficient so far.

\section{Conclusion}

Our study suggests a significant increase of symptomatic autoimmune thyroid disease, namely Hashimoto's thyroiditis, in pregnant women in Novi
Sad region during the last decade. Although the reasons have been discussed, they are still not known. Further follow up of this trend and detailed study of possible reasons are necessary. Due to the significance of proper treatment of hypothyroidism in pregnant women, it is recommended to introduce routine testing of all pregnant women in order to diagnose subclinical cases of pregnancy to start treatment on time.

\section{References}

1. Ostroumova E, Brenner A, Oliynyk V, McConnell R, Robbins J, Terekhova G, et al. Subclinical hypothyroidism after radioiodine exposure: Ukrainian-American cohort study of thyroid cancer and other thyroid diseases after the Chornobyl accident (1998-2000). Environ Health Perspect 2009;117(5):745-50.

2. Cardis E, Kesminiene A, Ivanov V, Malakhova I, Shibata $\mathrm{Y}$, Khrouch V, et al. Risk of thyroid cancer after exposure to 131I in childhood. J Natl Cancer Inst 2005;97(10):724-32.

3. Tronko MD, Brenner AV, Olijnyk VA, Robbins J, Epstein OV, McConnell RJ, et al. Autoimmune thyroiditis and exposure to iodine 131 in the Ukrainian cohort study of thyroid cancer and other thyroid diseases after the Chornobyl accident: results from the first screening cycle (1998-2000). J Clin Endocrinol Metab 2006;91(11):4344-51.

4. United Nations Enviroment Programme. Final act of the Conference of Plenipotentiaries on the Stockholm Convention on Persistent Organic Pollutants. New York, NY: United Natons Enviroment Programme, 2001.

5. UNEP/UNCHS Report The Kosovo Conflict. Consequences for the Enviroment \& Human Settlements: Geneva, 1999.

6. Boas M, Feldt-Rasmussen U, Main KM. Thyroid effects of endocrine disrupting chemicals. Mol Cell Endocrinol 2012; 355(2):240-8.

7. Lans MC, Klasson-Wehler E, Willemsen M, Meussen E, Safe S, Brouwer A. Structure-dependent, competitive interaction of hydroxy-polychlorobiphenyls, -dibenzo-p-dioxins and -dibenzofurans with human transthyretin. Chem Biol Interact 1993;88(1):7-21.

8. Schuur AG, Boekhorst FM, Brouwer A, Visser TJ. Extrathyroidal effects of 2,3,7,8-tetrachlorodibenzo-p-dioxin on thyroid hormone turnover in male Sprague-Dawley rats. Endocrinology 1997;138(9):3727-34.

9. Vial T, Nicolas B, Descotes J. Clinical immunotoxicity of pesticides. J Toxicol Environ Health 1996;48(3):215-29.

10. Langer P, Kausitz J, Tajtáková M, Kocan A, Bohov P, Hanzen E. Decreased blood level of beta 2-microglobulin in the employees of a factory which produced polychlorinated biphenyls. Chemosphere 1997;34(12):2595-600.

11. Duraković A. On depleted uranium: gulf war and Balkan syndrome. 2014;2(2):130-4.

12. Bleise A, Danesi PR, Burkart W.Properties, use and health effects of depleted uranium (DU): a general overview. J Environ Radioact 2003;64(2-3):93-112.

13. Miller AC, Stewart M, Brooks K, Shi L, Page N.Depleted uranium-catalyzed oxidative DNA damage: absence of significant alpha particle decay. J Inorg Biochem 2002;91(1):246-52.

14. Domingo JL.Reproductive and developmental toxicity of natural and depleted uranium: a review. Reprod Toxicol 2001; 15(6):603-9.
15. Ausó E, Lavado-Autric R, Cuevas E, Del Rey FE, Morreale De Escobar G, Berbel P. A moderate and transient deficiency of maternal thyroid function at the beginning of fetal neocorticogenesis alters neuronal migration. Endocrinology 2004;145(9):4037-47.

16. Lavado-Autric R, Ausó E, García-Velasco JV, Arufe Mdel C, Escobar del Rey F, Berbel P, et al. Early maternal hypothyroxinemia alters histogenesis and cerebral cortex cytoarchitecture of the progeny. J Clin Invest 2003;111(7):1073-82.

17. Sabo A, Stanulović M, Jakovljević V, Grujić Z. Collaborative study on drug use in pregnancy: the results of the follow-up 10 years after (Novi Sad Centre). Pharmacoepidemiology and drug Safety 2001;10:229-35.

18. [No authors listed] Medication during pregnancy: an intercontinental cooperative study. Collaborative Group on Drug Use in Pregnancy (C.G.D.U.P.). Int J Gynaecol Obstet 1992;39(3):185-96.

19. Tunbridge WM, Caldwell G. (1991) The epidemiology of thyroid diseases. In: L.E. Braverman, R.D. Utiger eds. The Thyroid: A fundamental and Clinical Text. Lippincot, Philadelphia.

20. Petersen K, Lindstedt G, Lundberg PA, Bengtsson C, Lapidus L, Nyström E. Thyroid disease in middle-aged and elderly Swedish women: thyroid-related hormones, thyroid dysfunction and goitre in relation to age and smoking. J Intern Med 1991;229(5):407-13.

21. Bjoro T, Holmen J, Krüger O, Midthjell K, Hunstad K, Schreiner T, Sandnes L, Brochmann H. Prevalence of thyroid disease, thyroiddysfunction and thyroid peroxidaseantibodies in a large, unselected population. The Health Study of NordTrondelag (HUNT). Eur J Endocrinol 2000; 143(5): 639-47.

22. Abalovich M, Amino N, Barbour LA, Cobin RH, De Groot LJ, Glinoer D, et al. Management of thyroid dysfunction during pregnancy and postpartum: an Endocrine Society Clinical Practice Guideline. Eur J Intern Med 2011;22(4):330-3.

23. Cruz-Cruz EA, Ramírez-Torres A, Pimentel-Nieto D, Roque Sánchez AM. Prevalence of clinical and subclinical hypothyroidism during pregnancy in a pregnant women population. Ginecol Obstet Mex 2014;82(11):717-24. [Article in Spanish]

24. Vanderpump MP. Should we treat mild subclinical $/ \mathrm{mild}$ hyperthyroidism? No. J Clin Endocrinol Metab 2007;92(8 Suppl):S1-47.

25. Wan B, Fleming JT, Schultz TW, Sayler GS. In vitro immune toxicity of depleted uranium: effects on murine macrophages, CD4+ T cells, and gene expression profiles. Environ Health Perspect 2006;114(1):85-91.

26. Bikit I, Slivka J, Conkić Lj, Krmar M, Vesković M, Zikić-Todorović N, Varga E, Curcić S, Mrdja D. Radioactivity of the soil in Vojvodina (northern province of Serbia and Montenegro). J Environ Radioact 2005;78(1):11-9. 
27. Sarap NB, Janković MM, Todorović DJ, Nikolić JD, Kovačević MS. Environmental radioactivity in southern Serbia at locations where depleted uranium was used. Arh Hig Rada Toksikol. 2014;65(2):189-97.

28. Škrbić B, Miljević N. An evaluation of residues at an oil refinery site following fires. J Environ Sci Health A Tox Hazard Subst Environ Eng. 2002;37(6):1029-39.

29. Škrbić B, Đurišić-Mladenović N. The sourcas of polychlorinated biphenyls in atmosphere. Gas. 2005;10(4):15-23.

30. Hagmar L, Rylander L, Dyremark E, Klasson-Wehler E, Erfurth EM. Plasma concentrations of persistent organochlorines in relation to thyrotropin and thyroid hormone levels in women. Int Arch Occup Environ Health. 2001;74(3):184-8.

31. Chevrier J, Eskenazi B, Holland N, Bradman A, Barr DB. Effects of exposure to polychlorinated biphenyls and organochlorine pesticides on thyroid function during pregnancy. Am J Epidemiol. 2008;168(3):298-310.

32. Takser L, Mergler D, Baldwin M, de Grosbois S, Smargiassi A, Lafond J. Thyroid hormones in pregnancy in relation to environmental exposure to organochlorine compounds and mercury. Environ Health Perspect. 2005;113(8):1039-45.

Rad je primljen 6. X 2015.

Recenziran 25. XI 2015.

Prihvaćen za štampu 27. XI 2015.

BIBLID.0025-8105:(2016):LXIX:1-2:11-15.
33. Jacobson JL, Jacobson SW. Association of prenatal exposure to an environmental contaminant with intellectual function in childhood. J Toxicol Clin Toxicol. 2002;40(4):467-75.

34. Vreugdenhil HJ, Mulder PG, Emmen HH, WeisglasKuperus N. Effects of perinatal exposure to PCBs on neuropsychological functions in the Rotterdam cohort at 9 years of age. Neuropsychology. 2004;18(1):185-93.

35. Langer P, Tajtakova M, Fodor G, Kočan A, Bohov P, Michalek J, et al. Increased thyroid volume and prevalence of thyroid disorders in an area heavily polluted by polychlorinated biphenyls. Eur J Endocrinol. 1998;139:402-3.

36. Mohandy R, S Patnaik, B Ramani:Subclinical hypothyroidis during pregnancy: A clinical review. Ind J Clin Pract. 2014;25(5):449-54.

37. Larson SD, Jackson LN, Riall TS, Uchida T, Thomas RP, Qiu S, et al. Increased incidence of well-differentiated thyroid cancer associated with Hashimoto thyroiditis and the role of the PI3k/Akt pathway. J Am Coll Surg. 2007;204(5):764-73.

38. Mijatović V, Samojlik I, Petković S, Horvat O, Tomić Z, Sabo A. Hormonal contraception - habits and awareness female students of the University of Novi Sad, Vojvodina, Serbia. Med Pregl. 2014;67(9-10):290-6. 